\title{
Implementation of Digital Technologies at Russian Enterprises as a Reserve for Increasing the Efficiency of Using Working Time
}

\author{
Elena A. Kipervar ${ }^{1, *}$ Ekaterina A. Kipervar $^{2}$ Anastasia V. Pobiyanskaya ${ }^{1}$ \\ ${ }^{1}$ Omsk state technical University, Omsk, 644050, Russia \\ ${ }^{2}$ Omsk state University. F. M. Dostoevsky, Omsk, 644077, Russia \\ *Corresponding author. Email: kipervar@list.ru
}

\begin{abstract}
The article is devoted to research of influence of introduction of digital technologies on efficiency of use of working hours. The purpose of work is revealing reserves of growth of efficiency of work based on rational use of working hours at the enterprises at use of achievements of digitalization. As a result of the conducted research reserves of growth of efficiency of use of working time are revealed, and as directions of improvement of balance of working time in the conditions of digitization are defined. The largest Russian companies engaged in the development and maintenance of systems of accounting and control of working time, the products offered by them and their scope of application are considered. Activity of the companies of the Omsk region which apply digital technologies in a direction of rational use of working hours is analyzed to improve work efficiency. Necessity of development and introduction of modern digital technologies, for increase of efficiency and labour productivity on the basis of researches which were carried out in the companies is argued. It was concluded that at present technical and technological capabilities are the main reserves of growth in the efficiency of working time use, which allows to increase productivity.
\end{abstract}

Keywords: digital economy, labor productivity, labor efficiency, working hours, reserves of labor productivity

growth, digital technologies

\section{INTRODUCTION}

In modern Russia, one of the priority areas of economic development is the growth of labor productivity, ensuring its advanced rate, which has been repeatedly voiced in the messages of the President of Russia to the Federal Assembly. As it is known, one of the main factors of labor productivity growth is the efficiency of working time use. Qualitative and rational use of working time is a direction every enterprise of the world aspires to, however, as practice shows, achievement of the set goal is not always feasible despite modern technologies and techniques. In this connection, the most important task is the search for additional reserves of growth efficiency of working time use as an individual employee, and the enterprise as a whole, which is a direction of labor productivity increase. At present, this area of activity is becoming more and more important. Its various sides are widely reflected in the works of economists Andreev I.D., Zanin V.I., Pozdnyakov V.Ya., Prudnikov V.M., Medvedeva Yu. In works of the presented authors separate aspects of the analysis of use of working time are covered, reserves of growth of productivity of labor, factors of growth of efficiency of labor are investigated. However, the published works do not fully consider the factors influencing the use of working time and the reserves of increasing its use, as well as their role in increasing productivity.

\subsection{Related Work}

The concept of time use efficiency reserves is closely related to the factors of its growth, which represent a real possibility, and can be translated into reality if supported by appropriate reserves. By studying time use efficiency growth reserves, their correlation with labor productivity growth reserves is traced (Fig. 1).

The reserves presented are not exhaustive, but may represent an option to consider unused opportunities from a practical perspective. Each block of reserves, in turn, is directly or indirectly related to the introduction and use of modern technologies that can optimize working time, reduce its losses, and identify additional opportunities for its rational use. Vladimir Putin notes that increasing the level of labor productivity at enterprises is achievable on the basis of new technologies and digitalization [2,3].

A clear classification of time consumption, its losses and cost rates is essential in determining the reserves for the growth of working time use. By improving the balance of working time, the efficiency of its use is increased (Fig. 2). A.O. Makarova, A.Sh. Galimova note "in the foreign economy regulations that determine the amount of working 
hours per unit of production have long occupied a leading position in organizational and managerial activities of enterprises" [1, c.156-157]. In modern conditions in Russia the decision of questions of the organization and rationing of work is transferred on enterprise level. At many enterprises quality of applied norms lags behind organizational and technical conditions of the given manufacture, and are outdated. The high level of the organization of work which is possible on the basis of use of scientifically proved norms is necessary. Such level, in turn, creates conditions for the application and introduction of progressive norms of labor, the definition of which takes into account social, economic and scientific and technical achievements.

When determining possible reserves for growth in the efficiency of working time use at Russian enterprises, most often timekeeping observations or a photograph of the

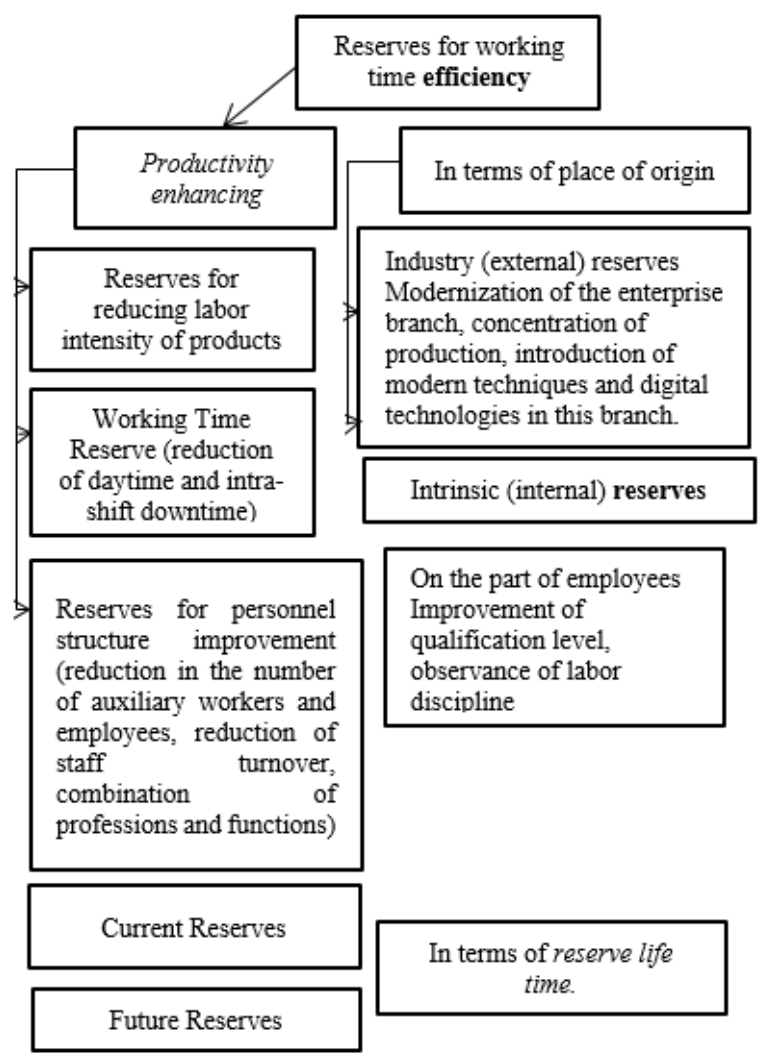

Figure 1 Reserves for increase in working time efficiency Source: developed by the authors working day shall be made, in cases which cannot be measured by time, the method of momentary observation shall be applied. These photographs of working hours can be used for rationing: preparatory and concluding time, time for servicing the workplace, time for rest and personal needs, number, service, as well as to identify the reasons for failure to comply with or exceeding the norms. However, in today's environment, it is possible to trace the replacement of traditional methods of studying working time with advanced digital technologies.

TAdviser, a Russian analytical agency, has identified 72 companies in Russia that develop and maintain time attendance and control systems [5,6]. The systems, which proved to be reliable and intuitive for the personnel of the companies, which provided the organizations with the effective timekeeping and control, are presented in Table 1.

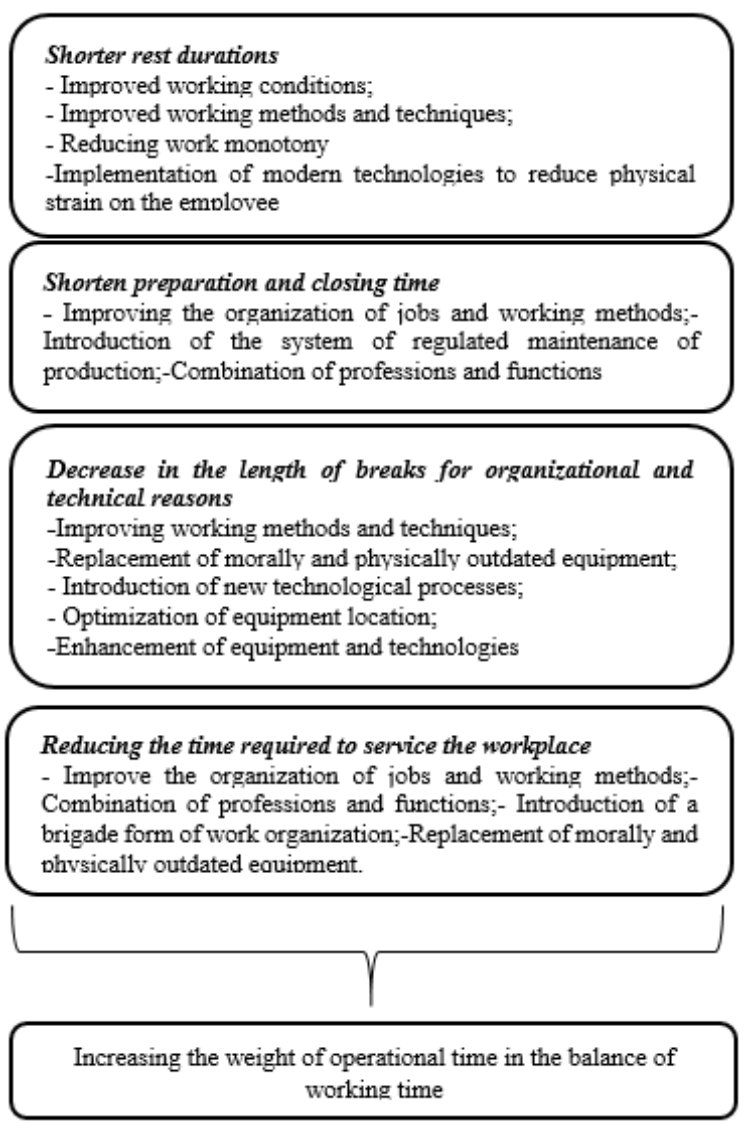

Figure 2 Directions for improvement of working time balance Source: developed by the authors 
Table 1 Sensor network experimental results

\begin{tabular}{|c|c|c|}
\hline Product & Solution & Company \\
\hline $\begin{array}{l}\text { Verint Impact } 360 \\
\text { WFM } \\
\text { Verint Workforce } \\
\text { Management }\end{array}$ & $\begin{array}{l}\text { Planning flexible staff schedules; forecasting daily and long-term } \\
\text { workloads; monitoring changes in workloads during the day; } \\
\text { monitoring operators' performance in real time }\end{array}$ & $\begin{array}{l}\text { Sberbank } \\
\text { VTB } 24\end{array}$ \\
\hline $\begin{array}{l}\text { Naumen Workforce } \\
\text { Management (WFM) }\end{array}$ & $\begin{array}{l}\text { Forecasting of workload, generation of reports on working time } \\
\text { use }\end{array}$ & $\begin{array}{l}\text { Ingosstrakh } \\
\text { Mosenergosbit }\end{array}$ \\
\hline APM Timebook & $\begin{array}{l}\text { Accounting and control of working time; face recognition } \\
\text { function, to determine the identity of the employee. }\end{array}$ & $\begin{array}{l}\text { M-Video, Lenta } \\
\text { Spar (СПАР Ритэйл) }\end{array}$ \\
\hline $\begin{array}{l}\text { BioSmart-WorkTime } \\
\text { [4] }\end{array}$ & $\begin{array}{l}\text { Possibility to control the attendance and work discipline of } \\
\text { employees; automatic recording of working hours of employees; }\end{array}$ & Ile De Bote etc. \\
\hline $\begin{array}{l}\text { Yaware. TimeTracker } \\
\text { (Yaware) }\end{array}$ & $\begin{array}{l}\text { Automatic time tracking: arrival and departure times, delays; } \\
\text { productivity analysis: based on which programs, applications and } \\
\text { sites employees use; control of freelancers and employees at } \\
\text { remote branches. Working out of system of bonuses for } \\
\text { employees, considering quantity of the worked time and } \\
\text { productivity. }\end{array}$ & Medtehnik etc. \\
\hline
\end{tabular}

Source: developed by the authors

Staff time management can be considered a fundamental factor in productivity and efficiency growth. The systems presented contribute to the optimization and control of working hours, to the solution of the problem associated with delays and premature leaving the workplace. In the course of modernization of the information environment, Russian and foreign companies started to introduce and use technologies that help to reduce staff working time losses and as a result increase company productivity [7].

Thus, the product "Verint Workforce Management" currently used by "Sberbank" and its branches, including Omsk, provided the company with the ability to accurately forecast the daily and long-term workload of several hundred employees. The result of the introduction of this system at the enterprise is "a reduction in unauthorized breaks in work and growth of productivity of employees" says the representative of Sberbank Alexander Semenov [9, 10]. One of the achievements of modern technologies to control and record working time is the Timebook ARM system consisting of "software and equipment, equipped with a digital camera with facial recognition function, designed to verify the identity of the employee" $[10,11,12]$. The importance of the product for modern companies is increased by the mobile application for recording and managing working time, with the help of which it is possible to track the work process of employees. BioSmartWorkTime product represents a biometric system identification by fingerprint. "By scanning a fingerprint, an employee marks the arrival and departure times" $[11,12,13,14]$. This product can be considered reliable in calculating the cost of working time relative to the beginning and end of the working day, as well as possible exits from the workplace.

Studying the enterprises of Omsk, it was found out that rather few companies have modern and reliable technologies of working time accounting, the main ways of working time control are automated control system and duty guard. Applied methods of accounting and control can not be fully considered objective, because, in the first case it is possible to use the executive mechanism (magnetic lock on the door, turnstile, barrier) by another employee of the company to change the data of excommunication from the workplace, arrival and departure, in the second case, there is a human factor that can reflect the changed data on the working time of employees, due to personal interest, friendly relations with colleagues.

In the city of Omsk, the innovators of the applied technologies are mainly the branches of Moscow and other cities of Russia - PJSC "Sberbank", VTB24, Ingosstrakh SPAO, M-video Eldorado, Ribbon, as well as foreign companies - Spar (SPAR Retail), Il De Bote United Europe, Leroy Merlin, IKEA. The presented companies repeatedly showed the importance of the introduction of advanced technologies and their role in the growth of labor productivity.

Among Omsk organizations we can single out Eurasia Motors (LLC "Eurasia Auto"), which uses the product "Alpha Auto: Car Showroom+Autoservice+Autospare Parts" to record the working hours of its employees. As Roman Pashnin, the manager of "Mitsubishi" center of "Eurasia-Motors" company, notes, "business processes of the company have been processed and optimized, which helped to reduce labor costs of employees" [8].

In order to increase the productivity of the enterprise and its financial return, Omsk companies need to take an example from advanced organizations that have shown the importance of modern technologies.

In addition to accounting and control products, the reserves for increasing the efficiency of working time use are reflected in special programs that reduce the loss of staff 
ConsultantPlus is used quite often at Russian enterprises, including Omsk and the Omsk Region, both at large corporations and at medium and small companies. However, despite the proven importance of this product in reducing working time losses and increasing staff productivity, many companies prefer to search for information on the Internet in order to save financial resources for software purchases. The given is first of all not safe for the company itself as the presented information can be outdated, secondly, information search in the Internet takes much more time that reduces efficiency of work of the personnel.

Considering growth potential of working time use effectiveness providing labour productivity increase, namely, introduction of modern technologies, at two enterprises of the city of Omsk the study of rationality of ConsultantPlus implementation was conducted. optimization of LAGR techniques. Our optimization can terminate the learning process in advance, if a counterexample appears in any membership and equivalence query.

Table 2 Comparative analysis of working hours to search for information in the legal reference system ConsultantPlus and the Internet

\begin{tabular}{|c|c|c|c|}
\hline \multirow{2}{*}{ Company name } & \multirow{2}{*}{ Department } & \multicolumn{2}{|c|}{ Average searching time, min } \\
\cline { 2 - 4 } & Lawyer A. & 1,1 & Consultant Plus \\
\hline \multirow{3}{*}{ «Lider» } & Lawyer B. & 2,3 & 8,0 \\
\cline { 2 - 4 } & Accountant & 1,5 & 7,5 \\
\cline { 2 - 4 } & Lawyer & 2,5 & 6,0 \\
\hline \multirow{3}{*}{ «Automatica» } & Accountant A. & 1,5 & 7,0 \\
\cline { 2 - 4 } & Accountant B. & 1,1 & 6,4 \\
\cline { 2 - 4 } & & 5,3 \\
\hline
\end{tabular}

Source: developed by the authors

The specialists of the companies under study were asked three questions each concerning their specialization, which did not require a lot of research materials and suggested an unambiguous solution. However, despite the simplicity of the questions, the search for an accurate answer on the Internet took more time, which indicates an irrational use of working time.

Thanks to the improvement of the technical capabilities of the SPS ConsultantPlus software, the company's specialists have saved time. Thus, for example, at the expense of annotations to decisions and regulations, perhaps without opening the document, to see the essence of the violation and responsibility for its commission, as well as the presence of hyperlinks in the documents to the mentioned in them norms of legal acts, allow to quickly move to the text of the relevant documents.

Introduction of the software capable to reduce losses of working hours of experts on information search, providing increase of labour productivity (table 3 ).

Table 3 Increase in labor productivity as a result of the implementation of the SPS ConsultantPlus

\begin{tabular}{|c|c|c|c|c|}
\hline \multirow{2}{*}{ Company name } & Department & Saving time, min. & $\begin{array}{c}\text { Possible saving of } \\
\text { time, per hour. }\end{array}$ & $\begin{array}{c}\text { Increase in labor } \\
\text { productivity, \%* }\end{array}$ \\
\hline \multirow{2}{*}{ «Lider» } & Lawyer A. & 6,9 & \multirow{2}{*}{6} & \multirow{2}{*}{3,58} \\
\cline { 2 - 3 } & Lawyer B. & 5,2 & 68,6 & \\
\cline { 2 - 3 } & Accountant & 4,5 & & 2,92 \\
\hline \multirow{2}{*}{ «Automatica» } & Lawyer & 4,5 & 56,2 & \multirow{2}{*}{} \\
\hline
\end{tabular}

Source: developed by the authors 
At the enterprises of OOO "Leader" and OOO "Automatics" due to time saving on information search the labor productivity increase was $3,58 \%$ and $2,92 \%$ respectively. This indicator indicates the rationality of software implementation. At the same time, if enterprises introduce time control and accounting systems, with the help of which it will be possible to exclude premature leaving the workplace and delays, as well as non-regulated rest breaks, productivity growth rate will increase.

\section{CONCLUSION}

To sum up, at present technical and technological capabilities are the main reserves of growth in the efficiency of working time utilization aimed at increasing labor productivity. Enterprises should strive to implement modern achievements for efficient work of the personnel.

\section{REFERENCES}

[1] Makarova, A.O.; Galimova, A.Sh. Directions of the working time use efficiency increase at the enterprise (in Russian) // Young scientist. - 2013. - №1. - C. 155158. - URL https://moluch.ru/archive/48/6061/ (date of address: 23.09.2019)

[2] Message from the President to the Federal Assembly ttp://kremlin.ru/events/president/news/59863

[3] Sberbank RF (Verint Impact 360 WFM - Verint Workforce Management) http://www.tadviser.ru/index.php/Проект:Сбербанк_P $\Phi \_$(Verint_Impact_360_WFM__Verint_Workforce_Management)

[4] https://www.bio-smart.ru/introductions

[5] https://www.bio-smart.ru/pages/sistema-uchetarabochego-vremeni-assorti

[6]http://www.tadviser.ru/index.php/Учет_рабочего_в ремени? cache $=$ no\&city $=$

[7] DBCDE (2013) promoting Australia as a digital economy: updating the national digital economy
The European Parliament (2015). Problems of competition policy in the digital economy. Brussels. Mode of access:

http://www.europarl.europa.eu/RegData/etudes/STUD/ 2015/542235/IPOL_STU(2015)542235_EN. Pdf

[8] Knickrehm, M., Berthon, B., Daugherty, P. Digital Disruption: The Growth Multiplier. Dublin: Accenture. [Electronic resource]. - Mode of access: https://www.accenture.com/_acnmedia/PDF4/Accenture-Strategy-Digital-разрушение-ростмультипликатор.pdf

[9] Lane, N. Advancing the Digital Economy into the 21st Century, Information Systems Frontiers, 1999, №3. P. 317-320.

[10] Lane, N. Promotion of the digital economy in the XXI century, borders of information systems, 1999, No. 3. Pp. 317-320.

[11] OECD (2013) the Digital Economy. Paris. - Mode of access:

http://www.oecd.org/daf/competition/TheDigitalэкономика-2012.pdf.

[12] Strategy . Canberra: Department of broadband, communications and the digital economy. [Electronic resource], Mode of access: http://apo.org.au/node/34523

[13] Tapscott, D. The Digital Economy: Promise and Peril in the Age of Networked Intelligence. New York / D. Tapscott. - NY: McGraw-Hill, 1996.

[14]https://www.itweek.ru/idea/article/detail.php?ID=1 35297.

[15] The President of Russia has congratulated "ConsultantPlus" on its 25th anniversaryhttp://www.consultant.ru/about/presscenter/ pressa3/pr_582/. 